\title{
Database of Halophytic Vegetation in Serbia
}

\author{
Zora Dajić Stevanović, Milicia Petrović, Urban Šilc \& Svetlana Aćić
}

\begin{abstract}
This paper describes the content of the vegetation database "Halophytic vegetation of Serbia" (GIVD ID EU-RS-001). The database of halophytic grassland vegetation in Serbia is held at Department of Botany, Faculty of Agriculture, Belgrade, Serbia. The database contains all available published relevé material (relevés originate from published sources and grey literature - theses, survey reports) from the territory of Serbia. Presently 1,026 relevés are available in the database which runs offline with TURBOVEG. All registered plant communities from phytosociological classes Thero-Salicornietea and Festuco-Puccinelietea are covered. The database is used for archiving relevé material, for preparation of classifications and other analyses of vegetation of Serbia and neighbouring countries.
\end{abstract}

Keywords: Festuco-Puccinelietea; Thero-Salicornietea.

GIVD Database ID: EU-RS-001

Last update: 2012-05-05

\section{Database of Halophytic Vegetation in Serbia}

Scope: In this vegetation database all phytosociological relevés and related vegetation samples (published and grey literature) from halophytic vegetation (Thero-Salicornietea and Festuco-Puccinelietea) in Serbia are stored.

Status: ongoing capture

Period: $1937-2002$

Database manager(s): Svetlana Aćić (acic@agrif.bg.ac.rs)

Owner: Zora Dajić Stevanović, Department of Botany, Faculty of Agriculture, Belgrade, Serbia (private)

Web address: [NA]

Availability: according to a specific agreement

Online upload: no

Online search: no

Database format(s): TURBOVEG

Export format(s): TURBOVEG

Publication: [NA]

Plot type(s): normal plots

Plot-size range: $1-100 \mathrm{~m}^{2}$

Non-overlapping plots: 1,026

Total plot observations: 1,026

Estimate of existing plots: [NA]

Number of sources: 45

Completeness: [NA]

Valid taxa: [NA]

Countries: RS: $100.0 \%$

Forest: [NA] — Non-forest: [NA]

Guilds: all vascular plants: $100 \%$

Environmental data: [NA]

Performance measure(s): cover: $100 \%$

Geographic localisation: [NA]

Sampling periods: [NA]

Information as of 2012-07-12; further details and future updates available from http://www.givd.info/ID/EU-RS-001

Zora Dajić Stevanović* (dajic@agrif.bg.ac.rs), Svetlana Aćić (acic@agrif.bg.ac.rs)

Department of Botany, Faculty of Agriculture, Nemanjina 6, 11080 Belgrade, SERBIA

Milica Petrović, (mpetrovic.azs@gmail.com)

Faculty of Tourism, University of Kragujevac, Vrnjacka Banja, SERBIA

Urban Šilc (urban@zrc-sazu.si)

Jovan Hadži Institute of Biology, ZRC SAZU, Novi trg 2, p.p. 306, 1001, Ljubljana, SLOVENIA

*Corresponding author 